\title{
Variation for nitrogen use efficiency traits in current and historical great plains hard winter wheat
}

\author{
Mary J. Guttieri · Katherine Frels • Teshome Regassa • \\ Brian M. Waters $\cdot$ P. Stephen Baenziger
}

Received: 24 September 2016/ Accepted: 1 March 2017/Published online: 15 March 2017

(C) The Author(s) 2017. This article is an open access publication

\begin{abstract}
Wheat genotypes that efficiently capture and convert available soil nitrogen into harvested grain protein are key to sustainably meeting the rising global demand for grain protein. The purposes of this study were: to characterize the genetic variation for nitrogen use efficiency (NUE) traits within hard winter wheat adapted to the Great Plains of the United States and evaluate trends in the germplasm with year of release; to explore relationships among traits that may be used for selection within breeding programs; and to identify quantitative trait loci associated with NUE traits in this germplasm. NUE traits were measured in a panel of 299 hard winter wheat genotypes, representing historically important and contemporary germplasm, from across the growing region. Trials
\end{abstract}

Electronic supplementary material The online version of this article (doi:10.1007/s10681-017-1869-5) contains supplementary material, which is available to authorized users.

M. J. Guttieri ( $\square)$

USDA Agricultural Research Service, Hard Winter Wheat

Genetics Research Unit, Manhattan, KS 66506-5502,

USA

e-mail: Mary.Guttieri@ars.usda.gov

K. Frels

Department of Agronomy and Plant Genetics, University of Minnesota, St. Paul, MN 55108-6026, USA

T. Regassa - B. M. Waters · P. S. Baenziger

Department of Agronomy and Horticulture, University of

Nebraska, Lincoln, NE 68583-0915, USA were grown in two years at two levels of nitrogen fertility. Genotype and genotype $\times$ year interaction effects were highly significant for NUE traits, while genotype $\times$ nitrogen rate interactions were non-significant. Strong genetic correlations of plant height and flowering date with NUE traits were observed. Wheat breeders have improved NUE: the subset of 183 genotypes that were released as cultivars after 1960 demonstrated significant trends with year of release for improved grain $\mathrm{N}$ yield, grain yield, nitrogen harvest index, nitrogen uptake efficiency, nitrogen utilization efficiency, and post-anthesis nitrogen uptake. In genome-wide association analyses, plant height and flowering date were important covariates in the mixed models, and plant height and flowering date substantially explained the variation in NUE traits in this germplasm. Marker-trait associations were identified that may prove useful in breeding.

Keywords Wheat - NUE - QTL · Grain protein deviation $\cdot$ Nitrogen harvest index

$\begin{array}{ll}\text { Abbreviations } \\ \text { FLO } & \text { Flowering (anthesis) date } \\ \text { HT } & \text { Plant height } \\ \text { NUE } & \text { Nitrogen use efficiency } \\ \text { GY } & \text { Grain yield per area } \\ \text { GNY } & \text { Grain nitrogen yield } \\ \text { GNC } & \text { Grain nitrogen concentration }\end{array}$




\begin{tabular}{|c|c|}
\hline GPC & Grain protein concentration \\
\hline GPD & Grain protein deviation \\
\hline NHI & Nitrogen harvest index \\
\hline NREM & Nitrogen remobilization \\
\hline NTA & Total nitrogen in plant at maturity per area \\
\hline $\mathrm{NTA}_{\max }$ & $\begin{array}{l}\text { Total N available to the crop per area, } \\
\text { estimated empirically as the } 95 \text { th } \\
\text { percentile of NTA }\end{array}$ \\
\hline NUE & Nitrogen use efficiency \\
\hline NUpE & Nitrogen uptake efficiency at maturity \\
\hline NUtE & Nitrogen utilization efficiency \\
\hline PANU & Post-anthesis nitrogen uptake \\
\hline SNC & $\begin{array}{l}\text { Straw nitrogen concentration, measured as } \\
\mathrm{N} \text { concentration in non-grain above- } \\
\text { ground dry matter at anthesis and maturity }\end{array}$ \\
\hline SY & $\begin{array}{l}\text { Straw yield at maturity, measured as } \\
\text { above-ground non-grain biomass per area }\end{array}$ \\
\hline
\end{tabular}

\section{Introduction}

Bread wheat (Triticum aestivum L.) is a primary staple cereal crop for human consumption with a global harvest of over 732 million MT from over 224 million hectares in 2015 (USDA-ERS 2016). Approximately $68 \%$ of the world wheat crop is used directly for food, and $21 \%$ is fed to livestock (Food Outlook: Global Market Analysis 2012). The U.S. Census Bureau projects that world population will grow from the present 7.3 billion to 9.4 billion by 2040 (United States Census Bureau 2016), which will increase the demand for staple food crops. Gilland (2006) estimates that the present per capita global average cereal production can be maintained through 2050 , but to do so will require a $50 \%$ increase in the use of nitrogen (N) fertilizer. Cereal crops with improved nitrogen use efficiency (NUE) could increase grain yield at a given level of $\mathrm{N}$ fertilizer.

Globally, 12.7 MMT of N were applied as fertilizer to wheat, while 38.1 MMT were applied to all crops (FAO 2006). Therefore, on a global basis, wheat accounts for nearly one-third of crop fertilizer use. From 1990 to 2010, average fertilizer use per acre of wheat in the United States was $75 \mathrm{~kg} \mathrm{ha}^{-1}$, and total average national use on wheat was 1.8 million nutrient tons (Economic Research Service 2013). Fertilizer cost has increased dramatically since 2000 , at an annual rate of nearly $10 \%$ each year. U.S. farm price for $\mathrm{N}$ fertilizer in 2012 tripled since 2002. Not surprisingly, U.S. fertilizer application rates on wheat have not risen since 1988. Consequently, wheat genotypes that efficiently capture and convert soil $\mathrm{N}$ into grain protein are key to sustainably meeting rising global demand for grain and grain protein.

Nitrogen use efficiency (NUE) is defined classically as the yield of grain per unit of available $\mathrm{N}$ (Moll et al. 1982). NUE is the net result of $\mathrm{N}$ capture (uptake efficiency) and $\mathrm{N}$ conversion (utilization efficiency) (Moll et al. 1982; Sylvester-Bradley and Kindred 2009). To assess $\mathrm{N}$ capture and conversion, four component measurements are required: grain yield (GY), grain $\mathrm{N}$ concentration (GNC), straw yield (SY, above-ground, non-grain biomass), and straw $\mathrm{N}$ concentration (SNC). The components of grain protein yield are GY and grain protein concentration (GPC), and these two traits are the two principle targets of most hard wheat improvement programs. Both parameters respond to $\mathrm{N}$ fertilization, yet it has been difficult to improve both yield and protein simultaneously. The negative relationship between grain yield and GPC is well established and has a genetic basis (Oury and Godin 2007; Bogard et al. 2010; Gaju et al. 2011; Oury et al. 2003; Barraclough et al. 2010; Simmonds 1995). Among 27 wheat genotypes grown in 27 environments ranging in available $\mathrm{N}$ (Bogard et al. 2010), mean grain yield variability accounted for $78 \%$ of mean GPC variability across all environments with a slope of $-0.015 \% \mathrm{~g}^{-1} \mathrm{~m}^{2}$. The two principle hypotheses to explain the negative correlation of grain yield and GPC are competition for energy resources by $\mathrm{C}$ and $\mathrm{N}$ assimilation processes (Munier-Jolain and Salon 2005) and a $\mathrm{N}$ dilution effect by carbohydrates (Acreche and Slafer 2009).

Grain $\mathrm{N}$ can be partitioned as coming from two sources: remobilization of $\mathrm{N}$ from vegetative tissues ( $\mathrm{N}$ remobilization, NREM) and $\mathrm{N}$ assimilated by the plant after anthesis (post-anthesis $\mathrm{N}$ uptake, PANU). In winter wheat ${ }^{15} \mathrm{~N}$ tracer studies, $71.2 \%$ of grain $\mathrm{N}$ originated from remobilization of pre-anthesis $\mathrm{N}$ (Kichey et al. 2007). Similarly, using subtraction analysis, Bogard (2010) determined that $76-80 \%$ of winter wheat grain $\mathrm{N}$ originated from remobilization, and genetic variability for NREM was low. Postanthesis $\mathrm{N}$ uptake and NREM are distinct processes. Although both PANU and NREM contribute to NUE, the traits were strongly negatively correlated ( $r=-0.51$ to -0.87 ) (Bogard et al. 2010). Grain 
protein deviation (GPD) is the deviation of observed GPC from the concentration predicted by the grain yield-GPC relationship. PANU, but not NREM, was significantly correlated $(r=0.67)$ with GPD. Selection for positive GPD has been proposed as a strategy for simultaneously improving grain yield and protein in wheat breeding (Monaghan et al. 2001; Guttieri et al. 2015).

Elite European winter wheat germplasm has demonstrated a trend toward improved nitrogen utilization efficiency (NUtE; grain yield per unit available $\mathrm{N}$ ) and nitrogen harvest index (NHI) over the last 25 years (Cormier et al. 2013). The levels of applied $\mathrm{N}$ fertilizer (as high as $250 \mathrm{~kg} \mathrm{ha}^{-1}$ ) and the crop yields (mean grain yields 5.8-9.0 $\mathrm{t} \mathrm{ha}^{-1}$ ) in these trials, however, were much higher than typical for the Great Plains of the United States. Some of the purposes of this study, therefore, were to characterize the genetic variation for NUE traits within Great Plains hard winter wheat germplasm and to evaluate trends in the germplasm with year of release. Previous studies in European germplasm and growing environments also have demonstrated that semi-dwarf stature (Gooding et al. 2012; Loddo and Gooding 2012) and flowering time (Bogard et al. 2011b) significantly affect NUE traits. Therefore this study also explored the relationships of plant height and flowering time with NUE parameters.

Phenotyping for NUE traits is laborious and costly; therefore linked molecular markers would be advantageous for breeding. QTL analyses to identify genomic regions associated with NUE have been conducted using both biparental recombinant inbred and doubled haploid populations from Asian and European germplasm in both seedling and full-season experiments (An et al. 2006; Guo et al. 2012; Sun et al. 2013; Xu et al. 2014; Laperche et al. 2006, 2007, 2008; Zheng et al. 2010; Fontaine et al. 2009; Habash et al. 2007; Garcia-Suarez et al. 2010; Bogard et al. 2011b, 2013). Association mapping (Bordes et al. 2013; Cormier et al. 2014) approaches also have been applied to NUE traits. These QTL analyses were recently reviewed by Cormier et al. (2016) and consistently indicate a large number (32-380) of small-effect QTLs for NUE traits. Similar studies have not been reported in North American winter wheat germplasm. Therefore this study used genome-wide association analysis with high-density SNP markers to identify genomic regions that may be associated with
NUE traits in Great Plains hard winter wheat germplasm.

\section{Materials and methods}

Germplasm

The test genotypes were a panel of 299 genotypes ( 258 hard red winter, 41 hard white winter) originating from both public and private wheat breeding programs in Colorado, Kansas, Montana, Nebraska, North Dakota, Oklahoma, South Dakota, and Texas. The panel was selected by breeders in the Great Plains region based on significance in production and/or contribution to the pedigrees of contemporary germplasm. Test genotypes in the panel included 193 cultivars and 106 breeding lines that were in advanced stages of testing in 2008. The test genotypes, their programs of origin, approximate release date, and pedigree are listed in Guttieri et al. (2015). Historical germplasm was included in the panel: the landrace, Turkey, the two ancestral cultivars, 'Cheyenne' and Kharkof, and five cultivars ('Comanche', 'Wichita', 'Kiowa', 'Bison', and 'Tascosa') developed before 1960.

\section{Experimental design}

Within each trial, nitrogen treatments (two rates) were applied as main plot treatments with two replications. Subplots of genotypes were arranged in 15 augmented incomplete blocks of two check genotypes ('Jagger' and 'Settler CL') with 20 test genotypes. These check genotypes also were included as test genotypes within the trial. The genotype Wichita was included twice in each trial. Therefore 60 plots of each of check genotype and 4 plots of each test genotype were grown in each environment.

\section{Agronomic management}

The experiment was grown at the University of Nebraska Agricultural Research and Development Center near Ithaca, NE. The soil type was a Sharpsburg silty clay loam, and soil test data were reported previously (Guttieri et al. 2015). Plots of each genotype were sown on Oct 42011 and Sept 252012 at approximately 260 seeds $\mathrm{m}^{-2}$ as four $3.2 \mathrm{~m}$ rows spaced $30 \mathrm{~cm}$ apart. To ensure adequate stand establishment, $1.8 \mathrm{~cm}$ of 
irrigation was applied to the 2013 trial on Oct 22012. Trials otherwise were rain-fed. Cumulative precipitation was reported previously (Guttieri et al. 2015). Trials were conducted under weed-free conditions, and in both years, multiple fungicide applications were made to control diseases. Details of pesticide applications are included in Online Resource 1.

Nitrogen rate treatments were established based on soil test data from samples collected in the spring of each year with the objective of providing contrasting levels of nitrogen availability (low, moderate) relative to a standard commercial target. Soil samples were collected to a depth of $25 \mathrm{~cm}$ on Mar 15 and 26 in 2012 and Apr 52013 in each of the 120 check plots in each year. Concentrations of macro- and micronutrients, $\mathrm{pH}$, and organic matter in soil samples was determined by Ward Labs (Kearney, NE). Nitrogen application rate was established based on target yields of $4000 \mathrm{~kg} \mathrm{ha}^{-1}$ in 2012 and $4700 \mathrm{~kg} \mathrm{ha}^{-1}$ in 2013. Target yield was adjusted upward in 2013 based on improved stand establishment, higher soil $\mathrm{pH}$ and soil $\mathrm{P}$ concentration, and a long, cool spring with abundant rain. Using the South Dakota State University (SDSU) fertilizer recommendation for wheat (Gerwing and Gelderman 2005), which is based on soil test $\mathrm{N}$ for the top $60 \mathrm{~cm}$ of soil and projects a crop requirement of $0.0417 \mathrm{~kg} \mathrm{ha}^{-1} \mathrm{~N}$ per kg ha ${ }^{-1}$ target yield, target $\mathrm{N}$ rates in the top $60 \mathrm{~cm}$ of soil were 167 and $196 \mathrm{~kg} \mathrm{ha}^{-1}$ in 2012 and 2013, respectively. From the standard commercial calculations for the region (Ward 2016), residual nitrate $\mathrm{N}$ in the top $60 \mathrm{~cm}$ was estimated to be 70.8 and $93.8 \mathrm{~kg} \mathrm{ha}^{-1}$ in late Spring of 2012 and 2013, respectively (Table 1). Fertilizer treatments were applied as $46 \%$ granular urea with a tractor-mounted drop spreader (Barber Engineering Company, Spokane, WA). In 2012, $15.6 \mathrm{~kg} \mathrm{ha}^{-1} \mathrm{~N}$ was applied in the spring to the low $\mathrm{N}$ main plot and $60.5 \mathrm{~kg} \mathrm{ha}^{-1} \mathrm{~N}$ was applied to the moderate $\mathrm{N}$ main plot on Mar 262012 when wheat was at early to mid- tillering (Zadoks stage 23-26). In 2013, no additional $\mathrm{N}$ was applied to the low $\mathrm{N}$ main plot, and $43.8 \mathrm{~kg} \mathrm{ha}^{-1}$ was applied to the moderate $\mathrm{N}$ main plot on Apr 292013 when wheat was at mid-tillering. Residual + applied $\mathrm{N}$ fertility in low $\mathrm{N}$ main plots was 52 and $48 \%$ of target $\mathrm{N}$ rates in 2012 and 2013, respectively. Residual + applied $\mathrm{N}$ fertility in moderate $\mathrm{N}$ main plots was $79 \%$ and $70 \%$ of target $\mathrm{N}$ rates in 2012 and 2013, respectively.

\section{Phenotypic measurements}

Anthesis or flowering date (FLO) was recorded visually as the date of anther exertion from $50 \%$ of main spikes. Physiological maturity date was recorded visually as the date of $90 \%$ chlorophyll depletion from the peduncle. Plant height (HT) was recorded at full stature as the height to the terminal spikelet less awns. Above ground biomass was collected at anthesis from $60 \mathrm{~cm}$ of row and $30 \mathrm{~cm}$ of row in 2012 and 2013, respectively. Samples were dried in forced air dryers at $55{ }^{\circ} \mathrm{C}$ for at least 7 days and weighed. At physiological maturity, above ground biomass was collected from $1 \mathrm{~m}$ of row and dried in forced air dryers at $55^{\circ} \mathrm{C}$ for at least 7 days. Total weight, spike count, and spike weight were recorded for all samples. Grain was harvested from manually detached spikes using a laboratory thresher (LD-180, Wintersteiger Inc., Salt Lake City, UT). In 2013, the procedure was modified to measure spike number and grain yield in a weighed subsample (approximately $200 \mathrm{~g}$ ) of the harvested material. Straw yield per area (SY) was calculated from the difference between total weight and grain yield. Above-ground non-grain biomass (straw + leaves, SNC) was ground on a Wiley 3 mill with a $2 \mathrm{~mm}$ screen. $\mathrm{N}$ concentration in ground tissue samples was measured by NIR reflectance using a Perten DA7250 spectrometer (Perten Instruments North America, Springfield, IL) calibrated to

Table 1 Spring residual and applied soil nitrogen and estimated total $\mathrm{N}$ available $\left(\mathrm{NTA}_{\max }\right)$ to low and moderate $\mathrm{N}$ treatments in 2012 and 2013

\begin{tabular}{llllll}
\hline Season & Residual soil N $\left(\mathrm{kg} \mathrm{N} \mathrm{ha}^{-1}\right)$ & \multicolumn{2}{l}{ Spring-applied N $\left(\mathrm{kg} \mathrm{N} \mathrm{ha}^{-1}\right)$} & & \multicolumn{2}{c}{$\mathrm{NTA}_{\max }\left(\mathrm{kg} \mathrm{N} \mathrm{ha}^{-1}\right)$} \\
& & Low N & Moderate N & Low N & 219 \\
\hline 2012 & 70.8 & 15.6 & 60.5 & 305 & 238 \\
2013 & 93.8 & 0 & 43.8 & 355 \\
\hline
\end{tabular}

$\mathrm{NTA}_{\text {max }}$ corresponds to the 95th percentile of total plant nitrogen per area at maturity for all the plots on the trial 
combustion analysis (LECO FP528, St. Joseph, MI). Grain N concentration (GNC) was determined by NIR reflectance (Perten DA7250 spectrometer) calibrated to combustion analysis (LECO FP528).

Total nitrogen in plants at maturity per area (NTA) was calculated as the sum of grain nitrogen yield $(\mathrm{GNY}=\mathrm{GNC} \times \mathrm{GY})$ plus straw nitrogen yield $(\mathrm{SNY}=\mathrm{SNC} \times \mathrm{SY})$. Nitrogen utilization efficiency (NUtE) was defined as the ratio of GY to NTA. Nitrogen Harvest Index (NHI) was defined as the ratio of $\mathrm{N}$ harvested as grain $(\mathrm{GY} \times \mathrm{GNC})$ to NTA. Grain protein deviation (GPD) was the residual from the linear regression of GPC on GY in each trial. Within each trial, the total $\mathrm{N}$ available to the crop was determined empirically as the 95th percentile of NTA $\left(\mathrm{NTA}_{\max }\right)$ as per Cormier et al. (2013). Nitrogen uptake efficiency (NUpE) at maturity was defined as the ratio NTA/NTA $\mathrm{Nax}_{\text {max }}$ Nitrogen remobilization (NREM) was calculated as the difference between anthesis $\mathrm{N}$ content and SNY. Post-anthesis nitrogen uptake (PANU) was calculated as the difference between NTA and anthesis nitrogen content.

\section{Statistical analysis}

Data were analyzed by mixed effects analysis of variance using ASReml-R (Butler et al. 2007). Year $(\mathrm{Y})$, and $\mathrm{N}$ rate $(\mathrm{N})$, and check cultivar $(\mathrm{C})$ were treated as fixed effects. Replication $(\beta)$, incomplete block $(I)$, and genotype $(g)$ were treated as random effects, in an extension of models developed by Wolfinger et al. (1997) and Federer (2005).

$$
\begin{aligned}
y= & \mu+\mathrm{Y}+\mathrm{N}+(\mathrm{Y} \times \mathrm{N})+\mathrm{C}+(\mathrm{Y} \times \mathrm{C}) \\
& +(\mathrm{N} \times \mathrm{C})+(\mathrm{Y} \times \mathrm{N} \times \mathrm{C})+\beta \\
: & \mathrm{Y}+\beta:(\mathrm{Y} \times \mathrm{N})+\beta \\
: & (\mathrm{Y} \times \mathrm{N} \times \mathrm{C})+I+g+(g \times \mathrm{Y})+(g \times \mathrm{N}) \\
& +(g \times \mathrm{Y} \times \mathrm{N})
\end{aligned}
$$

Significance of $\mathrm{N}$ rate was evaluated using Wald tests. Significance of $g, g \times \mathrm{Y}, g \times \mathrm{N}$, and $g \times \mathrm{N} \times \mathrm{Y}$ were evaluated using likelihood ratio tests. Genetic variance $\left(\sigma_{g}^{2}\right)$, genotype $\times$ Year variance $\left(\sigma_{g \times Y}^{2}\right)$, genotype $\times \mathrm{N}$ rate variance $\left(\sigma_{g \times N}^{2}\right)$, genotype $\times$ Year $\times \mathrm{N}$ rate variance $\left(\sigma_{g \times Y \times N}^{2}\right)$ were summed to estimate total variance associated with genotype, $\left(\sigma_{\text {Total }(g)}^{2}\right)$, so that the proportion of total genotype-associated variance due to $g, g \times \mathrm{Y}, g \times \mathrm{N}$, and $g \times \mathrm{N} \times \mathrm{Y}$ could be calculated for each trait. Broad-sense heritability was calculated on an entrymean basis as:

$H^{2}=\frac{\sigma_{g}^{2}}{\sigma_{g}^{2}+\frac{\sigma_{g x Y}^{2}}{2}+\frac{\sigma_{g X N}^{2}}{2}+\frac{\sigma_{g x N X Y}^{2}}{4}+\frac{\sigma_{e r r o r}^{2}}{8}}$

Because the genotype $\times$ year interaction generally contributed a substantial fraction of the variation associated with genotype, for the purposes of the association analyses and the analyses of time-related trends in the germplasm, best linear unbiased predictors (BLUPs) for test genotypes within each year were obtained in a two-step process. First, incomplete-block adjusted estimates for each genotype within each main plot were calculated. Then BLUPs were calculated from a standard split-plot analysis of variance with $\mathrm{N}$ rates as main plots and test genotypes as subplots. These genotype BLUPs will be publicly available on the T3 database (http://triticeaetoolbox.org.) following publication of this manuscript. Spearman rank correlations of the genotypes for each trait between the two years of the trial were calculated using the rcorr function in the Hmisc package in R (R Core Team 2016). Genetic improvements in NUE traits were evaluated with simple linear regression models of the NUE trait on release year for the 183 genotypes released after 1960. Based on the significant trends for decreased height and FLO with year of release, and the correlations of height and FLO with the most NUE traits, optimal multiple regression models using the predictor variables of release year, FLO, and height were selected using the Akaike's Information Criteria (AIC) in the step() function in $\mathrm{R}$. The rate of change with breeding $\left(\% \mathrm{yr}^{-1}\right)$ was calculated as the ratio of the coefficient of release year (slope) to the BLUP of the cultivar, 'Scout 66,' which is a long-term check cultivar used in regional cooperative yield testing nurseries.

Genotypic correlations $\left(r_{g}\right)$, phenotypic correlations $\left(r_{p}\right)$ of all traits and the standard deviations of these correlations were estimated in a pair-wise manner from the incomplete-block adjusted estimates for each test genotype in each main plot in each year using multivariate restricted maximum likelihood estimation in PROC MIXED in SAS v9.3 by extension of the method described by Holland (2006). Year, N rate, and replication were modeled as fixed effects; genotype, genotype $\times$ year, genotype $\times \mathrm{N}$ rate, and genotype $\times$ year $\times \mathrm{N}$ rate were modeled as random effects. 
Genome-wide association scans (GWAS)

High-density single-nucleotide polymorphism (SNP) marker data from the wheat $92 \mathrm{~K}$ iSelect assay (Wang et al. 2014) were used to identify potential marker-trait associations by GWAS. Data for 21,555 SNP were filtered to include only SNPs with a minor allele frequency (MAF) $>0.05$ and a fraction of lines with missing calls $<0.10$ to provide a total of 16,052 SNPs. Missing data were imputed with the EM algorithm in rrBLUP (Endelman 2011). Map positions for 14,829 SNP markers were as given in the $90 \mathrm{~K}$ consensus map downloaded from http://wheatgenomics.plantpath. ksu.edu on May 22, 2015; 1223 SNP markers were unmapped. SNP assay names are used in the text and tables. SNP data are available online (https:// triticeaetoolbox.org/wheat.). Association analysis was conducted with compressed mixed linear model (Zhang et al. 2010) implemented in the GAPIT $\mathrm{R}$ package (Lipka et al. 2012) with the option for optimal model selection using the Bayesian Information Criteria. Covariates provided to the model included FLO, HT, and four principal components calculated within GAPIT from the coancestry matrix. The model selection was provided with a kinship matrix calculated as the Realized Relationship Matrix of Endelman and Jannink (2012). A conservative threshold for marker significance was established based on an experiment-wise error rate of 0.05 using the estimated number of effective markers calculated as described by $\mathrm{Li}$ and $\mathrm{Ji}$ (2005). Linkage disequilibrium (LD) between significant markers was calculated using the LD function in the genetics package (Warnes et al. 2013) in R. Significant marker-trait associations were collapsed to QTLs based on LD relationship: markers with $r<0.8$ to the nearest significant marker were treated as distinct QTLs; markers with $r \geq 0.8$ to the nearest significant marker were collapsed in QTLs represented by the most highly significant SNP.

\section{Results}

Effect of growing conditions

The 2012 and 2013 growing seasons in NE were markedly different: the 2012 season was characterized by an early, warm spring and the 2013 season by a late, cool spring (Guttieri et al. 2015). Crop development consequently was markedly different in the two seasons. In 2012, the Jagger and Settler CL check plots reached anthesis on May-1 and May-6, respectively, and physiological maturity on Jun-5 and Jun11, respectively. In contrast, in 2013, the Jagger and Settler CL check plots reached anthesis on May-27 and May-31 and physiological maturity on Jun-27 and Jul-1, respectively. Mean grain yields in the 2012 and 2013 trials were 3580 and $5240 \mathrm{~kg} \mathrm{ha}^{-1}$, respectively. Mean grain yield in 2012 was below the target yield used to establish $\mathrm{N}$ rates (4000 $\mathrm{kg} \mathrm{ha}^{-1}$ ), and the low and moderate $\mathrm{N}$ treatments corresponded to 58 and $88 \%$ of target $\mathrm{N}$ for the mean yield of the trial. Mean grain yield in 2013 was above the target yield used to establish $\mathrm{N}$ rates $\left(4700 \mathrm{~kg} \mathrm{ha}^{-1}\right)$, and the low and moderate $\mathrm{N}$ treatments corresponded to 43 and $63 \%$ of target $\mathrm{N}$ for the mean yield of the trial.

\section{Effect of nitrogen rate}

The additional $\mathrm{N}$ provided by the moderate $\mathrm{N}$ rate treatment significantly increased grain $\mathrm{N}$ yield $(9.1 \%)$ and grain yield $(6.6 \%$, Table 2$)$. The moderate $\mathrm{N}$ treatment also significantly increased grain protein deviation, $\mathrm{N}$ utilization efficiency and post-anthesis nitrogen uptake. The effects of $\mathrm{N}$ rate were similar in the two years of the trial (non-significant $N$ rate $x$ year interaction, data not shown), except for PANU ( $N$ rate $\times$ year $\mathrm{F}=8.1, p<0.01)$. Nitrogen rate did not significantly affect flowering date, height, nitrogen harvest index, nitrogen uptake efficiency, or nitrogen remobilization. Genotypes responded similarly to nitrogen rates (non-significant genotype $\times \mathrm{N}$ rate interaction). The PANU response was complex, with significant genotype $\times \mathrm{N}$ rate $\times$ year interaction.

Genetic variance for nitrogen use efficiency traits

Wheat genotype was a significant source of variation for all NUE traits measured (Table 2) and for flowering date and plant height, and the genotype $\times$ year interaction was a significant source of variation for all NUE traits except NREM and PANU (however the three-way interaction of genotype $\times \mathrm{N}$ rate $\times$ year was significant for PANU). The contribution of genotype to the genetic components of variance (Table 2) was less than the contribution of the genotype $\times$ year interaction for GY, GNY, NHI, NUpE, and NUtE, which resulted in moderate 
Table 2 Effect of nitrogen rate, estimated broad-sense heritability, and contributions of genotype $(\mathrm{G})$, genotype $\times$ year $(\mathrm{G} \times \mathrm{Y}), \quad$ genotype $\times \mathrm{N}$ rate $(\mathrm{G} \times \mathrm{N})$ and

\begin{tabular}{|c|c|c|c|c|c|c|c|}
\hline Trait (units) & Low N & $\operatorname{Mod} N$ & $H^{2}$ & $\mathrm{G}(\%)$ & $\mathrm{G} \times \mathrm{Y}(\%)$ & $\mathrm{G} \times \mathrm{N}(\%)$ & $\mathrm{G} \times \mathrm{Y} \times \mathrm{N}(\%)$ \\
\hline Flowering date & 138.6 & 138.3 & 0.79 & $66^{* * * *}$ & $33 * * *$ & $1 \mathrm{~ns}$ & Ons \\
\hline Height $(\mathrm{cm})$ & 86.0 & 86.0 & 0.91 & $87 * * *$ & $12.3 * * *$ & Ons & $1 \mathrm{~ns}$ \\
\hline Grain $\mathrm{N}$ yield $\left(\mathrm{kg} \mathrm{N} \mathrm{ha}^{-1}\right)$ & 121 & $132 * * *$ & 0.36 & $31 * * *$ & $66 * * *$ & 0 & $3 \mathrm{~ns}$ \\
\hline Grain protein deviation $\left(\mathrm{g} \mathrm{kg}^{-1}\right)$ & -2.9 & $2.9^{*}$ & 0.63 & $58 * * *$ & $35 * * *$ & 0 & $7 \mathrm{~ns}$ \\
\hline Grain yield $\left(\mathrm{kg} \mathrm{ha}^{-1}\right)$ & 4520 & $4820^{*}$ & 0.43 & $35 * * *$ & $62 * * *$ & 0 & $3 \mathrm{~ns}$ \\
\hline Nitrogen harvest index & 0.618 & 0.613 & 0.48 & $40 * * *$ & $53 * * *$ & $2 \mathrm{~ns}$ & $4 \mathrm{~ns}$ \\
\hline NREM $\left(\mathrm{kg} \mathrm{N} \mathrm{ha}^{-1}\right)$ & 150 & 143 & 0.41 & $55^{* * *}$ & $16 \mathrm{~ns}$ & 0 & $28 \mathrm{~ns}$ \\
\hline NUpE & 0.78 & 0.75 & 0.25 & $30 *$ & $48 * *$ & 0 & $22 \mathrm{~ns}$ \\
\hline NUtE $\left(\mathrm{kg}\right.$ grain $\left.(\mathrm{kg} \mathrm{N})^{-1}\right)$ & 23.3 & $22.4 * *$ & 0.53 & $43 * * *$ & $52 * * *$ & 0 & $5 \mathrm{~ns}$ \\
\hline PANU $\left(\mathrm{kg} \mathrm{N} \mathrm{ha}^{-1}\right)$ & -29.3 & $-11.0 * * *$ & 0.54 & $64 * * *$ & $7 \mathrm{~ns}$ & Ons & $29 *$ \\
\hline
\end{tabular}

***,*** Significance at $p<0.05,0.01$, and 0.001, respectively. Significance of N rate was evaluated using Wald tests. Significance of the genetic components of variance was evaluated using likelihood ratio tests

heritability estimates for these traits $(0.25-0.53)$. Grain protein deviation was the most heritable NUE trait (0.63).

\section{Correlations between traits}

The estimates of phenotypic and genotypic correlations of traits from multivariate multi-location analysis (Table 3) demonstrate that plant height and flowering date were positively correlated $\left(r_{g}=\right.$ $0.67 \pm 0.04 ; r_{p}=0.52 \pm 0.03$; Table 3). Genotypic correlations of HT and FLO were negative with all NUE traits except NREM, with which they were positively correlated. Earlier and shorter wheat genotypes tended to be more nitrogen use efficient genotypes. NREM and PANU were strongly negatively correlated $\left(r_{g}=-0.94 \pm 0.04 ; r_{p}=-0.89 \pm 0.01\right)$. Genotypic correlations of GNY and GY were negatively with NREM and positively with PANU; the relationships were stronger for GNY than for GY. PANU had relatively weak genotypic correlation $\left(r_{g}=0.37 \pm 0.12\right)$ with NUtE, but strong genotypic correlation $\left(r_{g}=0.72 \pm 0.10\right)$ with NHI. For some combinations of traits, the genotypic and phenotypic correlations were similar (e.g. GY and GNY, GY and NUpE, NUtE and NHI); for many combinations of traits the genotypic correlations had much greater magnitude than the corresponding phenotypic correlations (e.g. NREM and FLO, HT and NUpE, PANU and $\mathrm{NHI})$.

\section{Phenotypic data by year}

Given the substantial genotype $\times$ year interactions, the data for the two years were analyzed separately to generate estimates (BLUPs) of genotype performance within each year for use in subsequent analyses. These data, summarized in Figs. 1 and 2, demonstrate that the difference in early spring temperatures in the two years (2012 was a warm, early spring; 2013 was a cool, late spring) resulted in a 23 day delay in flowering in 2013 relative to 2012. Plants in 2013 were, on average, $18.3 \mathrm{~cm}$ taller than in 2012 (Fig. 1). Because of the extended period of pre-anthesis growth in 2013, mean dry matter at anthesis was $11,960 \mathrm{~kg} \mathrm{ha}^{-1}$, nearly double the mean dry matter at anthesis $\left(6020 \mathrm{~kg} \mathrm{ha}^{-1}\right)$ in 2012 (Fig. 2). Straw yield (SY) at maturity in the two years was not proportional to dry matter at anthesis: SY averaged $6200 \mathrm{~kg} \mathrm{ha}^{-1}$ in 2012, but only $9350 \mathrm{~kg} \mathrm{ha}^{-1}$ in 2013. Grain N yield in 2013 was $36 \%$ greater than in 2012. N remobilization was $143 \%$ greater in 2013 than in 2012, while PANU was, on average, positive in 2012 and negative in 2013. On average, less $\mathrm{N}$ was measured in above-ground tissues at maturity than at anthesis in 2013. NHI and NUtE were lower, NUpE was higher, and NREM was much higher in the high-yield conditions of 2013 than in 2012. Plants had greater N uptake and remobilization in high-yield conditions, but used the $\mathrm{N}$ less efficiently to produce yield and protein.

The Spearman rank correlations of the genotypes between the two years of the trial were strongly 


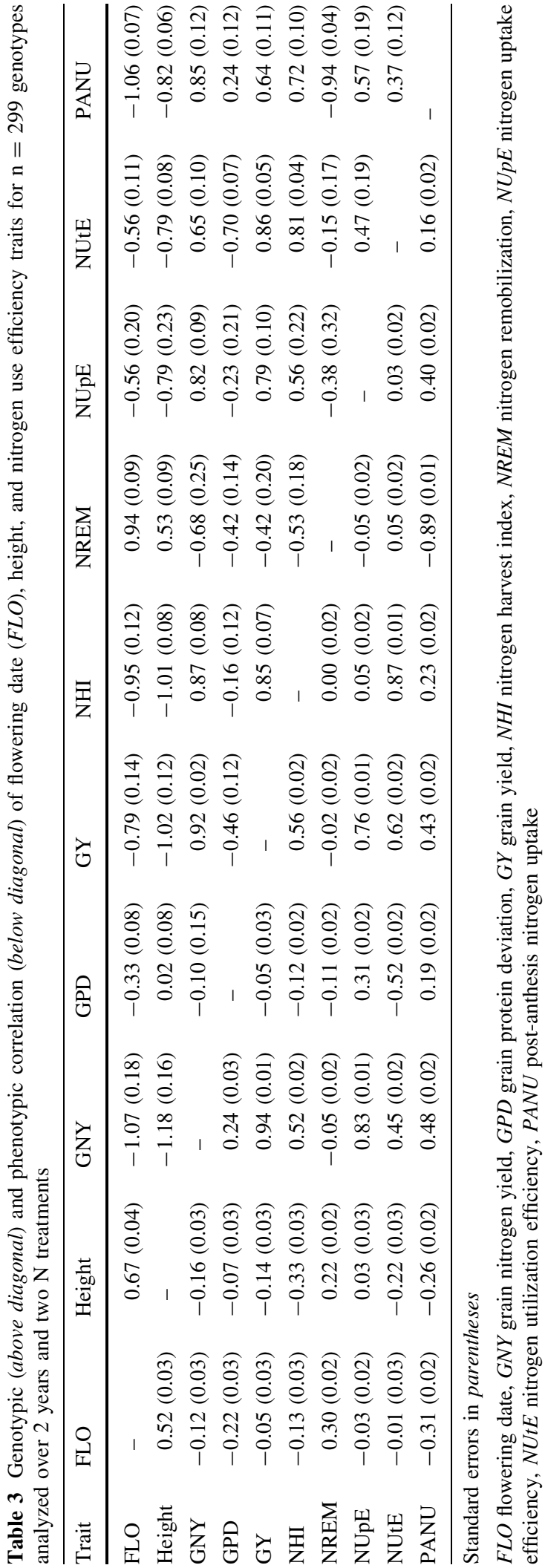

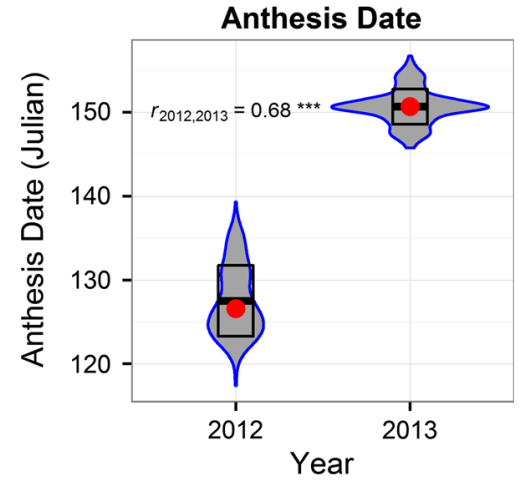

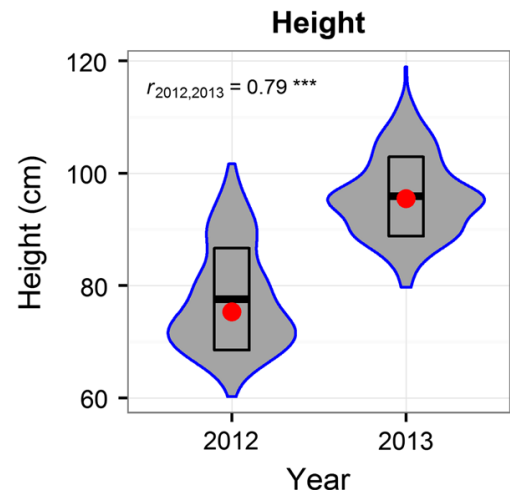

Fig. 1 Distributions of best linear unbiased predictors (BLUPs) of plant height and flowering date for 299 genotypes grown in 2012 and 2013. The center, top, and bottom of the boxes indicate the mean, mean plus one standard deviation, and mean minus one standard deviation, respectively. Red dots indicate the median. Width of the violins are drawn proportional to the frequency distribution of BLUPs. Spearman rank correlation coefficients for genotype BLUPs in the two trial years are indicated for each trait; $\mathrm{n}=299$ and three asterisks indicates significance of correlation coefficients at $p<0.001$

positive for flowering date $(r=0.68, \mathrm{n}=299$, $p<0.001)$ and plant height $(r=0.79, \mathrm{n}=299$, $p<0.001$, Fig. 1). Correlations were weaker for grain protein deviation $(r=0.42, \mathrm{n}=299, p<0.001)$ and NUtE and PANU $(r=0.35, \mathrm{n}=299, p<0.001$ and $r=0.34, \mathrm{n}=299, p<0.001$, respectively, Fig. 2). Correlations were significant for all traits other than NUpE, and are generally consistent with the rankings of the estimated heritabilities (Fig. 2).

Trends in germplasm

In both 2012 and 2013, simple linear regression of the genotype BLUPs for HT, FLO, and the NUE traits on release year for the 183 cultivars released after 1960 was significant for most traits (Table 4). Anthesis date 
Fig. 2 Distributions of best linear unbiased predictors (BLUPs) of nitrogen use efficiency traits for 299 genotypes grown in 2012 and 2013. The center, top, and bottom of the boxes indicate the mean, mean plus one standard deviation, and mean minus one standard deviation, respectively. Red dots indicate the median. Width of the violins are drawn proportional to the frequency distribution of BLUPs. Spearman rank correlation coefficients for genotype BLUPs in the two trial years are indicated for each trait; $\mathrm{n}=299$, $\mathrm{ns}=$ non-significant, and three asterisks indicates significance of correlation coefficients at $p<0.001$
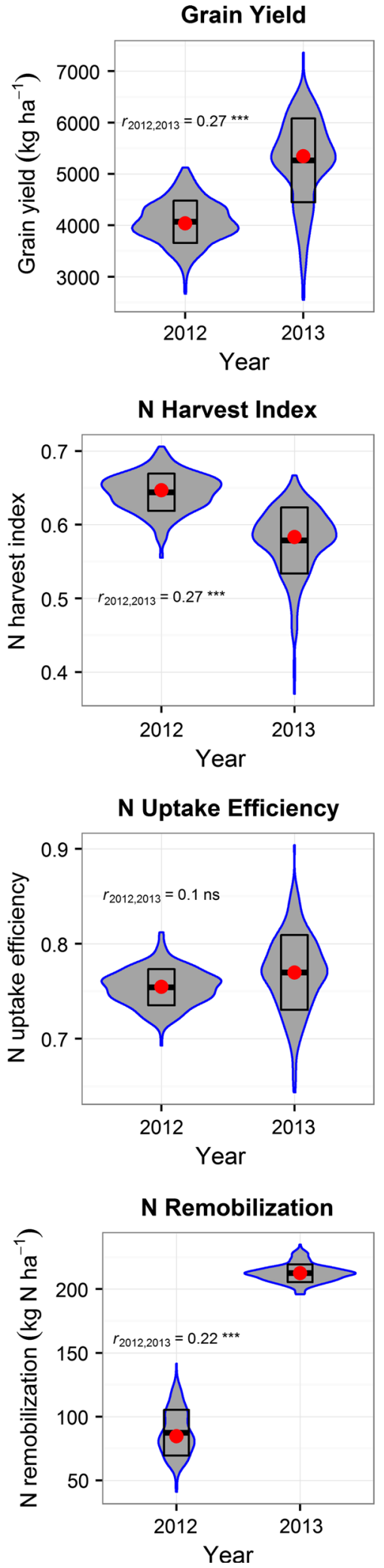
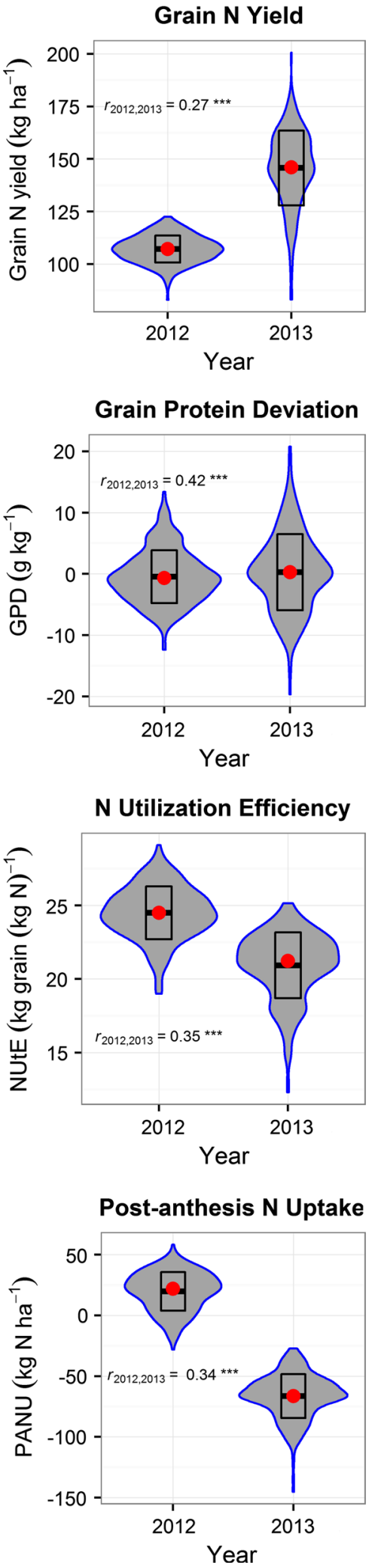


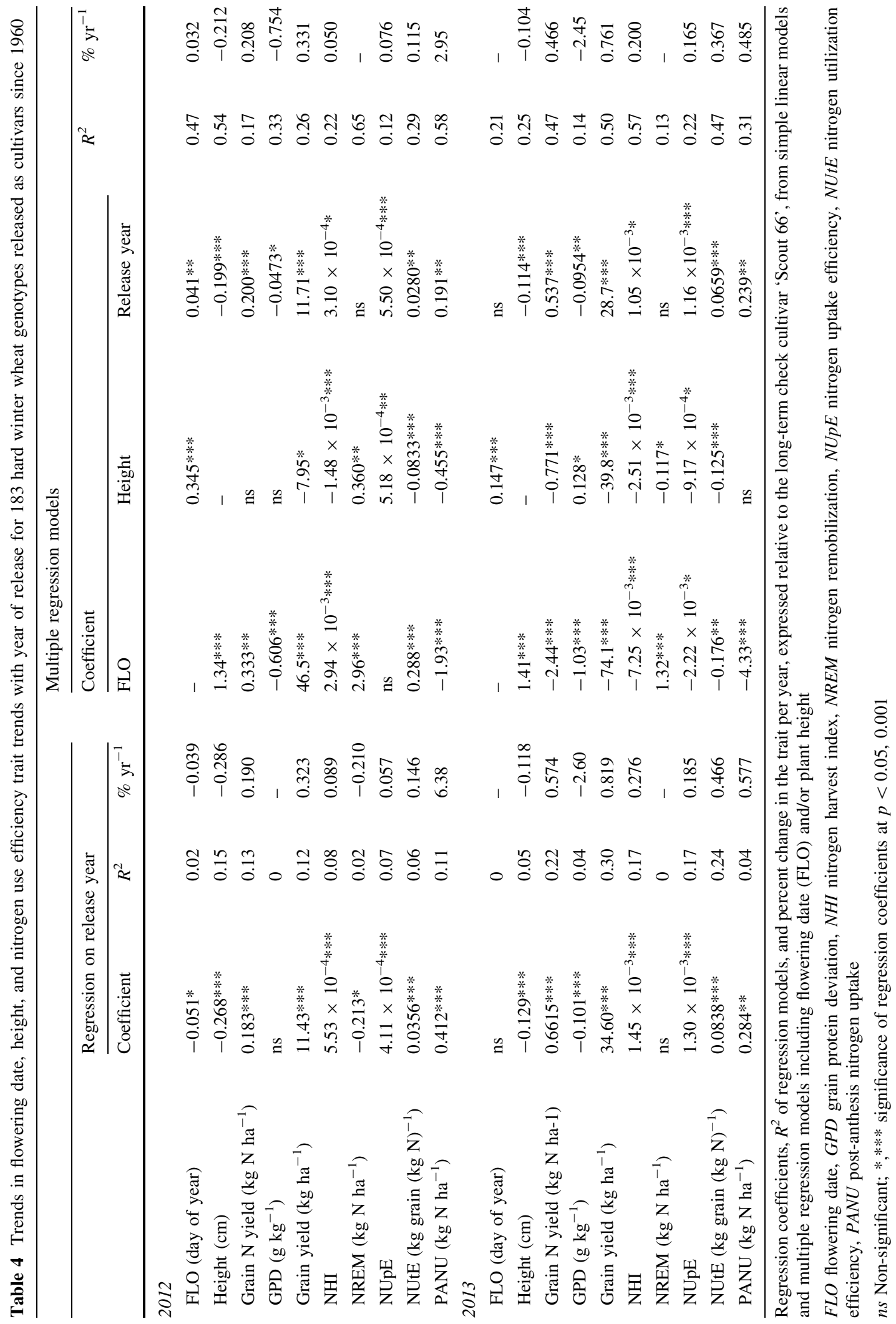


and NREM regression on release year were weakly significant $(p=0.03$ and $p=0.04)$ in 2012 and nonsignificant $(p>0.05)$ in 2013. GPD regression on release year was non-significant $(p>0.05)$ in 2012, but was highly significant $(p=0.003)$ in the highyield conditions of 2013. With the exception of PANU, the slope of the regressions was greater under the high-yield conditions of 2013. The trends in the germplasm indicate increasing PANU, NUpE, NHI, NUtE, GNY, and GY with year of release.

Accounting for FLO and/or HT in multiple regression models with release year substantially improved the accuracy of models for NUE traits as demonstrated by the greater $R^{2}$ values (Table 4 ). In 2012, the trend was for earlier FLO with year of release in the simple linear model. But when HT was accounted for in the regression model, the model fit improved greatly and the trend was for later FLO with year of release. The model coefficients for year of release were attenuated in the multiple regression models, relative to the simple linear models, providing more conservative estimates of genetic progress for NUE traits, accounting for trends in HT and FLO.

Genome-wide association scans (GWAS)

Our objective in GWAS was to identify genomic regions associated specifically with NUE traits, rather than to identify genomic regions associated with height and flowering time. The strong genetic correlations of HT and FLO with NUE traits indicated that HT and FLO would be important covariates in the GWAS. Therefore, a model selection approach with HT, FLO, and principal components supplied as possible covariates was used to identify the optimal model, based on Bayesian Information Criteria, then to evaluate the effects of markers after accounting for these fixed effects. Model selection retained height as a covariate for every NUE trait in each year, and retained FLO as a covariate in all cases, excepting $\mathrm{NUpE}$ in 2012. The first principal component was retained as a covariate only for NUtE and GNY in 2013. The covariates, together with the kinship matrix, explained as much as $65 \%$ of the variance for individual NUE traits (Table 5).

Applying the liberal threshold of marker significance of $p<0.001$, as in Cormier (2015), a total of 224 significant marker associations were identified for the eight NUE traits (GNY, GY, GPD, NHI, NUpE,
NUtE, NREM, PANU, Online Resource 2). These associations involved 183 unique SNP markers distributed across every chromosome except 6D and 7D. Sixteen of the SNP markers with significant associations were unmapped. The maximum improvement in model $R^{2}$ with the addition of a SNP marker was 0.051. A more conservative threshold for marker significance based on an experiment-wise error rate of $5 \%$ and estimating the effective number of marker tests according to Li and Ji (2005) applied a threshold of $p<1.168 \times 10^{-4}$ for significance. Li and Ji's method accounts for the correlation among the markers, and estimated that the 16,052 markers effectively provided 439 marker tests. At this threshold, 42 significant marker associations with the eight NUE traits were identified in the two years, 15 in 2012 and 27 in 2013 (Online Resource 2). The marker associations involved 25 SNP markers on 5 chromosomes (1A, 1D, 2B, 2D, and 4B) and three unmapped SNPs. This conservative set of associations will be the focus of the subsequent discussion.

In 2012, IWA693 (Chr 1A, $152.2 \mathrm{cM})$ was significantly associated with GNY (Table 5). IWA693 also had $p<0.001$ association with GY in 2012. Six associations were detected for GPD in 2012, on Chr 1D (112.7 cM), 2B (119.1 cM), 2D $(80.1 \mathrm{cM})$, and three unmapped SNPs. The peak SNP on 2D associated with GPD in 2012 (IWB43945) also was significantly associated with NHI and NUtE in 2012.

In 2013, a SNP on Chr 2D, (IWB74084, $76.6 \mathrm{cM})$, was significantly associated with GNY, and NUpE (Table 5). This SNP was in weak LD $(r=0.30)$ with IWB43945, which was important in 2012. Two SNPs on Chr 4B, (IWB27326 and IWA7566, located at 61.8 and $80.6 \mathrm{cM}$, respectively), were significantly associated with GPD in 2013. These SNPs were in higher LD ( $r=0.50)$ than would be expected based on the consensus map positions. Both SNPs had low minor allele frequency (MAF), $\leq 17 \%$. A set of 10 SNPs on $\mathrm{Chr} 4 \mathrm{~B}$ that were in high linkage disequilibrium with each other $(r>0.9)$, represented by IWB34983 $(64.26 \mathrm{cM})$, were significantly associated with NHI in 2013. Two additional SNPs on Chr 4B in moderately high LD with this block of SNPs $(r>0.7)$ also were significantly associated with NHI. IWB34983 and SNPs in high LD with IWB34983 also were significantly associated with NUtE in 2013 and had $p<0.001$ association with GNY and GY in 2013. No 
Table 5 Covariates retained in genome-wide association analyses and peak mapped SNP associated with nitrogen use efficiency traits

\begin{tabular}{|c|c|c|c|c|c|c|c|}
\hline Trait & Covariates retained & SNP location (pos) ${ }^{\dagger}$ & Peak SNP & $R^{2}$ without SNP & $R^{2}$ with SNP & MAF & Effect \\
\hline \multicolumn{8}{|l|}{2012} \\
\hline GNY & $\begin{array}{l}\text { FLO, } \\
\text { Height }\end{array}$ & $\begin{array}{l}1 \mathrm{~A} \\
(152.2)\end{array}$ & IWA693 & 0.172 & 0.219 & 0.248 & -1.76 \\
\hline GPD & $\begin{array}{l}\text { FLO, } \\
\text { Height }\end{array}$ & $\begin{array}{l}\text { 1D (112.7) } \\
\text { 2B (119.1) } \\
\text { 2D (80.1) }\end{array}$ & $\begin{array}{l}\text { IWA7023 } \\
\text { IWB5957 } \\
\text { IWB43945 }\end{array}$ & $\begin{array}{l}0.351 \\
0.351 \\
0.351\end{array}$ & $\begin{array}{l}0.390 \\
0.386 \\
0.385\end{array}$ & $\begin{array}{l}0.405 \\
0.318 \\
0.182\end{array}$ & $\begin{array}{l}-0.97 \\
0.94 \\
1.10\end{array}$ \\
\hline GY & $\begin{array}{l}\text { FLO, } \\
\text { Height }\end{array}$ & & & 0.265 & & & \\
\hline NHI & $\begin{array}{l}\text { FLO, } \\
\text { Height }\end{array}$ & $2 \mathrm{D}(80.1)$ & IWB43945 & 0.310 & 0.355 & 0.182 & -0.008 \\
\hline NREM & $\begin{array}{l}\text { FLO, } \\
\text { Height }\end{array}$ & & & 0.650 & & & \\
\hline NUpE & Height & & & 0.047 & & & \\
\hline NUtE & $\begin{array}{l}\text { FLO, } \\
\text { Height }\end{array}$ & 2D (80.1) & IWB43945 & 0.368 & 0.411 & 0.182 & -0.54 \\
\hline PANU & $\begin{array}{l}\text { FLO, } \\
\text { Height }\end{array}$ & & & 0.561 & & & \\
\hline \multicolumn{8}{|l|}{2013} \\
\hline GNY & $\begin{array}{l}\text { FLO, } \\
\text { Height, } \\
\text { PC1 }\end{array}$ & 2D (76.6) & IWB74084 & 0.488 & 0.516 & 0.130 & 4.56 \\
\hline GPD & $\begin{array}{l}\text { FLO, } \\
\text { Height }\end{array}$ & $\begin{array}{l}4 \mathrm{~B}(61.8) \\
4 \mathrm{~B} \\
(80.6)\end{array}$ & $\begin{array}{l}\text { IWB27326 } \\
\text { IWA7566 }\end{array}$ & $\begin{array}{l}0.131 \\
0.131\end{array}$ & $\begin{array}{l}0.182 \\
0.182\end{array}$ & $\begin{array}{l}0.170 \\
0.144\end{array}$ & $\begin{array}{l}-2.25 \\
-2.21\end{array}$ \\
\hline GY & $\begin{array}{l}\text { FLO, } \\
\text { Height }\end{array}$ & & & 0.507 & & & \\
\hline NHI & $\begin{array}{l}\text { FLO, } \\
\text { Height }\end{array}$ & $\begin{array}{l}4 \mathrm{~B} \\
(64.2)\end{array}$ & IWB34983 & 0.555 & 0.591 & 0.469 & -0.011 \\
\hline NREM & $\begin{array}{l}\text { FLO, } \\
\text { Height }\end{array}$ & & & 0.119 & & & \\
\hline NUpE & $\begin{array}{l}\text { FLO, } \\
\text { Height }\end{array}$ & $\begin{array}{l}2 \mathrm{D} \\
(76.6)\end{array}$ & IWB74084 & 0.231 & 0.276 & 0.130 & 0.013 \\
\hline NUtE & $\begin{array}{l}\text { FLO, } \\
\text { Height, } \\
\text { PC1 }\end{array}$ & $\begin{array}{l}4 B \\
(64.2)\end{array}$ & IWB34983 & 0.495 & 0.534 & 0.469 & -0.487 \\
\hline PANU & $\begin{array}{l}\text { FLO, } \\
\text { Height }\end{array}$ & & & 0.328 & & & \\
\hline
\end{tabular}

FLO flowering date, MAF minor allele frequency, $P C 1$ principal component 1

$\dagger$ Chromosome and position (pos) in centimorgans are as given in the consensus map downloaded from http://wheatgenomics. plantpath.ksu.edu. on May 22, 2015

Only SNP associations significant at an experiment-wise error rate of $5 \%$ are presented 
significant marker associations with GY, NREM, or PANU were detected in either 2012 or 2013 at the more conservative threshold of $p<1.168 \times 10^{-4}$.

The minor alleles of the most significant SNPs generally had adverse effects on NUE traits (Table 5), which indicates that favorable alleles for NUE have been selected in breeding. Exceptions, cases in which the less common allele was favorable, were the $2 \mathrm{~B}$ and 2D SNPs for GPD in 2012, and the 2D SNP associated with GNY and NUpE in 2013. Increasing the frequency of these alleles in hard winter wheat germplasm may lead to improved NUE.

\section{Discussion}

\section{Genetic variance for NUE traits}

Genetic variation for NUE traits is present within the Great Plains hard winter wheat germplasm pool. Among the eight NUE traits evaluated in this study, grain protein deviation, post-anthesis nitrogen uptake, and $\mathrm{N}$ utilization efficiency had the greatest broad sense heritability. Genotype $\times$ environment interaction effects were highly significant, likely due to variation in genetic responses to the very different spring temperature conditions in the two years of the trial. The proportion of genetic variance for GY due to genotype $(35 \%)$ and genotype $\times$ year interaction $(62 \%)$ were substantially different than in the European study reported by Cormier et al. (2013) (genotype $=60 \%$, genotype $\times$ env $=36 \%)$. Mean grain yield ( $4670 \mathrm{~kg} \mathrm{ha}^{-1}$ ) and the heritability of grain yield (0.43) were substantially lower in our study than in European trials (mean grain yield $=7400 \mathrm{~kg} \mathrm{ha}^{-1}$, heritability $=0.79$ ). However, GNY was nearly identical to the European study, due to low grain protein concentration (mean 9.93\%) in Cormier et al. (2013), compared to $15.2 \%$ and $15.9 \%$ in our study in 2012 and 2013, respectively. Nitrogen uptake efficiency was similar to the European study, but nitrogen utilization efficiency (22.9) was lower than in the European study (48.8). Nitrogen harvest index was greater $(0.812)$ in the European study than in our work (0.615). Genotype $\times \mathrm{N}$ interaction was not an important source of variation in our study, perhaps because the two rates of $\mathrm{N}$ were similar. The high grain mean protein concentrations in our study $(>15 \%)$ indicate that the crop was not grown under $\mathrm{N}$-limiting conditions.
Reducing post-anthesis $\mathrm{N}$ loss, and improving PANU, would be tremendously valuable to NUE. We observed significant genetic variation for the trait, although there was a complex relationship of genotype, $\mathrm{N}$ rate, and year. Mean PANU among the genotypes in 2013 was negative (Fig. 2, $-66.4 \mathrm{~kg} \mathrm{~N}$ $\mathrm{ha}^{-1}$ ), while in 2012, mean PANU was positive $\left(19.7 \mathrm{~kg} \mathrm{~N} \mathrm{ha}^{-1}\right)$. Post-anthesis nitrogen loss of similar magnitude has been reported previously for wheat (Papakosta and Gagianas 1991). Ammonia loss from the tops of plants is reportedly the major mechanism of $\mathrm{N}$ loss (Harper et al. 1987; Farquhar et al. 1980), and losses are greatest under conditions of high evapotranspiration rates: low humidity, high temperature, and good available soil moisture. In the 14 days following mean anthesis date, the average daily temperature was $18.8 \mathrm{C}$ in 2012 and $18.7 \mathrm{C}$ in 2013. Average relative humidity was somewhat lower in this period during $2013(73.6 \%)$ than in 2012 $(81.7 \%)$. Soil moisture conditions following anthesis were very good in both years. Therefore, environmental conditions following anthesis may not explain the difference between the two years in PANU. The mean anthesis date in 2012 was 23 days earlier than in 2013 (Fig. 1), which shortened the growing season and contributed to reduced average total dry matter at anthesis in 2012. This difference in dry matter at anthesis in the two years was reflected in lower $\mathrm{N}$ content at anthesis, $144 \mathrm{~kg} \mathrm{~N} \mathrm{ha}^{-1}$, in 2012, compared to $317 \mathrm{~kg} \mathrm{~N} \mathrm{ha}^{-1}$ in 2013 . Yet average grain $\mathrm{N}$ yield was only $36 \%$ greater in 2013 than in 2012, and grain yield was only 29\% greater in 2013 than in 2012 (Fig. 2), which suggests that sink capacity may not have increased in proportion to source in the long season, high yield conditions in 2013. After accounting for the effects of plant height and flowering time, no significant SNP associations with PANU were identified at the conservative threshold, and only 11 significant SNP associations on Chr 5A, 2B, 2D, 3D, and 5D were identified at the more liberal $p<0.001$ threshold (Online Resource 2).

\section{Genotypic correlations among traits}

Correlations among NUE traits are expected based on the numerical interdependence of the traits. Genotypic and phenotypic correlations of traits (Table 3) were most similar for traits with numerical interdependence. For example, the nitrogen utilization efficiency 
trait uses grain yield as the numerator in the calculation, and nitrogen harvest index uses grain nitrogen yield as the numerator in calculation. PANU and NREM were strongly negatively correlated $\left(r_{g}=-0.94 \pm 0.04 ; r_{p}=-0.89 \pm 0.01\right)$. This correlation is based on the calculation of the traits. PANU is the difference between total $\mathrm{N}$ yield at maturity and total $\mathrm{N}$ yield at anthesis. As $\mathrm{N}$ yield at anthesis increases, other terms being equal, PANU decreases and NREM increases; and as straw $\mathrm{N}$ at maturity increases, other terms being equal, PANU increases and NREM decreases. Among the NUE traits, GPD generally was least correlated with the other traits. This would be anticipated because it is a measure of deviation from the physiological relationship between yield and grain protein. The absence of strong genetic correlations with other traits suggests that GPD may be manipulated independently.

In contrast, genetic correlations of plant height and flowering date, and genetic correlations of these traits with NUE traits, indicate pleiotropy. Flowering date and plant height genetic correlations with NUE traits generally were very strong, while phenotypic correlations with NUE traits generally were much weaker (Table 3). Phenotypic correlation of two traits, $\mathrm{X}$ and $\mathrm{Y}$, results from the combined effect of both genetic and environmental correlation:

$r_{p}=h_{X} h_{Y} r_{g}+e_{X} e_{Y} r_{E}$

where $h$ is the square root of the heritability, $e$ is the square root of the proportion of phenotypic variance attributable to environment, E (Falconer and Mackay 1996). When heritability is low, and when $r_{E}$ is low, phenotypic correlation may be much less than genotypic correlation. In a review of 32 plant studies in which both phenotypic and genotypic correlations were reported, Waitt and Levin (1998) found that the magnitude of correlation in genotypic correlation matrices was greater than in phenotypic correlation matrices in $85 \%$ of studies. They also noted that the traits for which phenotypic and genotypic correlations were most similar for traits that belonged to the same functionally and/or developmentally related set that they described as being "a higher degree of genetic and phenotypic character integration." The important effect of flowering time has been observed in phenotypic correlations reported in other NUE studies (Bogard et al. 2011a; Laperche et al. 2007; Cormier et al. 2013). The magnitude of the genotypic correlations of FLO and HT with NUE traits in our study were much greater than the magnitude of phenotypic correlations reported previously.

\section{Genetic improvement in NUE traits}

Wheat breeding within the Great Plains of the United States has improved nitrogen use efficiency: within the subset of 183 cultivars released from 1960 to 2014, coefficients of the regression on release year for key NUE traits were significant and positive in both years of the study (Table 4). Accounting for trends in flowering time and plant height attenuated but did not negate the estimates of gain in NUE parameters. Genetic improvement of NUtE was positive in both $2012\left(0.115 \% \mathrm{yr}^{-1}\right)$ and $2013\left(0.367 \% \mathrm{yr}^{-1}\right)$, after accounting for changes in HT and FLO (Table 4). However, the rate of genetic improvement we observed for NUtE was approximately one-half the rate of improvement we observed for grain yield in $2012\left(0.331 \% \mathrm{yr}^{-1}\right)$ and $2013\left(0.761 \% \mathrm{yr}^{-1}\right)$. Nitrogen harvest index improved at a rate of $0.05 \% \mathrm{yr}^{-1}$ in 2012 and $0.20 \% \mathrm{yr}^{-1}$ in 2013. Previous estimates for the rate of improvement of NHI in European germplasm were $0.15 \% \mathrm{yr}^{-1}$ (Brancourt-Hulmel et al. 2003) and $0.12 \% \mathrm{yr}^{-1}$ (Cormier et al. 2013). It appears, therefore, that yield gains have come primarily through increased dry matter, rather than through efficient uptake and remobilization of $\mathrm{N}$.

Association analysis

At a liberal threshold of marker significance, a total of 224 significant marker associations involving 183 unique SNP markers were identified for the eight NUE traits. These markers were distributed across every chromosome except 6D and 7D. QTL effects were modest: the maximum improvement in model $R^{2}$ with the addition of a SNP marker was 0.051. At a more conservative threshold for marker significance, a threshold of $p<1.168 \times 10^{-4}$ for significance, 42 significant marker associations involving $25 \mathrm{SNP}$ markers on 5 chromosomes (1A, 1D, 2B, 2D, and 4B) and three unmapped SNPs were identified in the two years. Previous QTL studies have identified between 32 and 380 QTLs for NUE traits (Cormier et al. 2016).

The strong genotypic correlations of flowering date and height with NUE traits was reflected in the high model $R^{2}$ for most of the trait-year combinations in the 
absence of any fitted SNPs. Despite attempting to control for the effects of plant height in the GWAS models, SNP markers on Chr 4B were significantly associated with GPD and NHI in 2013. Rht-Blb, located on chromosome $4 \mathrm{~B}$, became the prevalent allele for semi-dwarf stature in modern Great Plains hard winter wheat after the late 1970s (Guedira et al. 2010). Grogan et al. (2016) found that $72 \%$ of the genotypes included in this study were homozygous for the semi-dwarf-allele $R h t-B 1 b$. The significant SNP markers on $4 \mathrm{~B}$ in this study were in moderate LD $(r=0.58)$ with the Rht-B1 marker data previously reported for 291 of these genotypes (Grogan et al. 2016). The GPD-associated SNP alleles are at a relatively low frequency in the population of lines (14-17\%), and have a negative effect on GPD, while the NHI-associated SNP alleles are present at a relatively high frequency (47\%) and likewise have a negative effect on NHI and on NUtE. Therefore the favorable 4B alleles for NUE traits appear to be widely distributed in the Great Plains hard winter wheat germplasm. The 4B QTLs may not be a consequence of Rht-B1. GSe, a cytosolic gene encoding glutamine synthetase, maps near $R h t-B 1$, and the temporal profile of its activity suggests that it is a key gene involved in $\mathrm{N}$ remobilization (Habash et al. 2007; Fontaine et al. 2009).

In both years, SNP markers on the long arm of Chr 2D were associated with NUE traits, which suggests that this may be a fertile target for future investigation. The favorable 2D alleles for NUE traits were present at low frequency $(0.13-0.18)$ in the germplasm included in this study. Previous studies that have identified NUE associations with 2D have localized on or near the Ppd-D1 locus for photoperiod sensitivity on 2DS (Cormier et al. 2014; Laperche et al. 2007). In contrast, the SNPs we have identified map to 2DL and are not in LD with previously reported $P p d-D 1$ marker data for these genotypes (Grogan et al. 2016). Glutamine synthase 2 genes are located in distal deletion bins on the long arms of group 2 chromosomes and are potential candidates for future investigation, given their important role in previous studies (Li et al. 2011).

\section{Conclusions}

Nitrogen use efficiency has improved in the Great Plains hard winter wheat germplasm in the period from 1960 to 2014, even after controlling for the effects of changes in height and heading date in this time period. Genotypic correlations of height and flowering date with NUE traits other than grain protein deviation were highly significant, and height and flowering date were retained as covariates in GWAS models for NUE traits in both years of the trial for most traits. In many cases, height and flowering date explained substantial proportions of the variation in the GWAS. Including height and flowering date as covariates may be a useful approach in other studies. Our results point to the difficulty inherent in identifying alleles for improved NUE within un-adapted germplasm: confounding effects of non-adaptive phenology may obscure modest improvements in $\mathrm{N}$ uptake, assimilation, or remobilization. Moreover, bi-parental populations with uniform phenology may be most effective for mapping of NUE QTLs.

Using a conservative threshold of marker significance for GWAS, a limited number of significant marker-trait associations were identified in the Great Plains hard winter wheat germplasm that may have future utility in breeding. However, relative to the effects of flowering time and height, marker effects were small. Consistent, favorable associations with NUE traits were identified on 2DL that merit further investigation within germplasm with uniform flowering time and plant height to better quantify the marker allele effects independent of phenological adaptation. The favorable alleles on 2DL were relatively rare in the Great Plains hard winter wheat germplasm, indicating that 2DL may be a fertile region for continued study.

Acknowledgements We are grateful for the technical assistance of Lega Dolicho, Greg Dorn, Amy Hauver, Madison Hergenrader, Melinda Knuth, Neal Mattox, Patrick Souza, and Carter Westerhold. We wish to acknowledge Dr. Shiaoman Chao of the USDA-ARS Regional Genotyping Laboratory in Fargo, ND for conducting the iSelect assays that provided the SNP data for this manuscript. Furthermore, we grateful to the numerous plant breeders and geneticists from the public and private sector who developed or submitted their lines for inclusion in the Hard Winter Wheat Association Mapping Panel. Mention of trade names or commercial products in this publication is solely for the purpose of providing specific information and does not imply recommendation or endorsement by the U.S. Department of Agriculture. USDA is an equal opportunity provider and employer.

Funding This project was supported by the National Research Initiative Competitive Grants 2011-68002-30029 and 2017-67007-25939 from the USDA National Institute of Food and Agriculture. 


\section{Compliance with ethical standards}

Conflict of interest The authors declare that they have no conflict of interest.

Open Access This article is distributed under the terms of the Creative Commons Attribution 4.0 International License (http:// creativecommons.org/licenses/by/4.0/), which permits unrestricted use, distribution, and reproduction in any medium, provided you give appropriate credit to the original author(s) and the source, provide a link to the Creative Commons license, and indicate if changes were made.

\section{References}

Acreche MM, Slafer GA (2009) Variation of grain nitrogen content in relation with grain yield in old and modern Spanish wheats grown under a wide range of agronomic conditions in a Mediterranean region. $J$ Agric Sci 147:657-667. doi:10.1017/s0021859609990190

An DG, Su JY, Liu QY, Zhu YG, Tong YP, Li JM, Jing RL, Li B, Li ZS (2006) Mapping QTLs for nitrogen uptake in relation to the early growth of wheat (Triticum aestivum L.). Plant Soil 284(1-2):73-84. doi:10.1007/s11104-0060030-3

Barraclough PB, Howarth JR, Jones J, Lopez-Bellido R, Parmar S, Shepherd CE, Hawkesford MJ (2010) Nitrogen efficiency of wheat: genotypic and environmental variation and prospects for improvement. Eur J Agron 33(1):1-11. doi:10.1016/j.eja.2010.01.005

Bogard M, Allard V, Brancourt-Hulmel M, Heumez E, Machet J-M, Jeuffroy M-H, Gate P, Martre P, Le Gouis J (2010) Deviation from the grain protein concentration-grain yield negative relationship is highly correlated to post-anthesis $\mathrm{N}$ uptake in winter wheat. J Exp Bot 61(15):4303-4312

Bogard M, Jourdan M, Allard V, Martre P, Perretant MR, Ravel C, Heumez E, Orford S, Snape J, Griffiths S, Gaju O, Foulkes J, Le Gouis J (2011a) Anthesis date mainly explained correlations between post-anthesis leaf senescence, grain yield, and grain protein concentration in a winter wheat population segregating for flowering time QTLs. J Exp Bot 62(10):3621-3636. doi:10.1093/jxb/ err061

Bogard M, Jourdan M, Allard V, Martre P, Perretant MR, Ravel C, Heumez E, Orford S, Snape J, Griffiths S, Gaju O, Foulkes J, Le Gouis J (2011b) Anthesis date mainly explained correlations between post-anthesis leaf senescence, grain yield, and grain protein concentration in a winter wheat population segregating for flowering time QTLs RID B-8806-2009. J Exp Bot 62(10):3621-3636

Bogard M, Allard V, Martre P, Heumez E, Snape JW, Orford S, Griffiths S, Gaju O, Foulkes J, Le Gouis J (2013) Identifying wheat genomic regions for improving grain protein concentration independently of grain yield using multiple inter-related populations. Mol Breed 31(3):587-599. doi:10.1007/s11032-012-9817-5

Bordes J, Ravel C, Jaubertie JP, Duperrier B, Gardet O, Heumez E, Pissavy AL, Charmet G, Le Gouis J, Balfourier F (2013) Genomic regions associated with the nitrogen limitation response revealed in a global wheat core collection. Theor Appl Genet 126(3):805-822

Brancourt-Hulmel M, Doussinault G, Lecomte C, Berard P, Le Buanec B, Trottet M (2003) Genetic improvement of agronomic traits of winter wheat cultivars released in France from 1946 to 1992. Crop Sci 43(1):37-45

Butler D, Cullis BR, Gilmour AR, Gogel BJ (2007) ASReml-R reference manual. 2.0 edn. Brisbane, Queensland

Cormier F, Faure S, Dubreuil P, Heumez E, Beauchene K, Lafarge S, Praud S, Le Gouis J (2013) A multi-environmental study of recent breeding progress on nitrogen use efficiency in wheat (Triticum aestivum L.). Theor Appl Genet 126(12):3035-3048. doi:10.1007/s00122-0132191-9

Cormier F, Le Gouis J, Dubreuil P, Lafarge S, Praud S (2014) A genome-wide identification of chromosomal regions determining nitrogen use efficiency components in wheat (Triticum aestivum L.). Theor Appl Genet 127(12):2679_ 2693. doi:10.1007/s00122-014-2407-7

Cormier F, Foulkes J, Hirel B, Gouache D, Moenne-Loccoz Y, Le Gouis J (2016) Breeding for increased nitrogen-use efficiency: a review for wheat (T. aestivum L.). Plant Breed 135(3):255-278. doi:10.1111/pbr.12371

Economic Research Service (2013) Fertilizer Use and Price: Table 2- U.S. plant nutrient use by corn, soybeans, cotton, and wheat, 1964-2012. United States Department of Agriculture. http://www.ers.usda.gov/data-products/ fertilizer-use-and-price.aspx\#26751. Accessed 5 May 2013

Endelman JB (2011) Ridge Regression and other kernels for genomic selection with R Package rrBLUP. Plant Genome 4(3):250-255. doi:10.3835/plantgenome2011.08.0024

Endelman JB, Jannink JL (2012) Shrinkage estimation of the realized relationship matrix. G3-genes genomes. Genetics 2(11):1405-1413. doi:10.1534/g3.112.004259

Falconer DS, Mackay TFC (1996) Introduction to quantitative genetics, 4th edn. Pearson Education Ltd., Edinburgh Gate

FAO (2006) Fertilizer use by crop. FAO Fertilizer and Plant Nutrition Bulletin, Rome

Farquhar GD, Firth PM, Wetselaar R, Weir B (1980) On the gaseous exchange of ammonia between leaves and the environment-determination of the ammonia compensation point. Plant Physiol 66(4):710-714. doi:10.1104/pp. 66.4.710

Federer WT (2005) Augmented split block experiment design. Agron J 97(2):578-586

Fontaine J-X, Ravel C, Pageau K, Heumez E, Dubois F, Hirel B, Le Gouis J (2009) A quantitative genetic study for elucidating the contribution of glutamine synthetase, glutamate dehydrogenase and other nitrogen-related physiological traits to the agronomic performance of common wheat. Theor Appl Genet 119(4):645-662

Food Outlook: Global Market Analysis (2012)

Gaju O, Allard V, Martre P, Snape JW, Heumez E, Le Gouis J, Moreau D, Bogard M, Griffiths S, Orford S, Hubbart S, Foulkes MJ (2011) Identification of traits to improve the nitrogen-use efficiency of wheat genotypes. Field Crops Res 123(2):139-152

Garcia-Suarez JV, Roder MS, de Leon JLD (2010) Identification of QTLs and associated molecular markers of agronomic traits in wheat (Triticum aestivum L.) under two conditions 
of nitrogen fertilization. Cereal Res Commun 38(4):459470. doi:10.1556/crc.38.2010.4.2

Gerwing J, Gelderman R (2005) Fertilizer recommendation guide. South Dakota State University, Brookings

Gilland B (2006) Population, nutrition and agriculture. Popul Environ 28(1):1-16

Gooding MJ, Addisu M, Uppal RK, Snape JW, Jones HE (2012) Effect of wheat dwarfing genes on nitrogen-use efficiency. J Agric Sci 150:3-22

Grogan SM, Brown-Guedira G, Haley SD, McMaster GS, Reid SD, Smith J, Byrne PF (2016) Allelic variation in developmental genes and effects on winter wheat heading Date in the US great plains. PLoS ONE 11(4):e0152852. doi:10. 1371/journal.pone.0152852

Guedira M, Brown-Guedira G, Van Sanford D, Sneller C, Souza E, Marshall D (2010) Distribution of Rht genes in modern and historic winter wheat cultivars from the Eastern and Central USA. Crop Sci 50(5):1811-1822. doi:10.2135/ cropsci2009.10.0626

Guo Y, Kong FM, Xu YF, Zhao Y, Liang X, Wang YY, An DG, Li SS (2012) QTL mapping for seedling traits in wheat grown under varying concentrations of $\mathrm{N}, \mathrm{P}$ and $\mathrm{K}$ nutrients. Theor Appl Genet 124(5):851-865. doi:10.1007/ s00122-011-1749-7

Guttieri MJ, Baenziger PS, Frels K, Carver B, Arnall B, Waters BM (2015) Variation for grain mineral concentration in a diversity panel of current and historical great plains hard winter wheat germplasm. Crop Sci 55(3):1035-1052

Habash DZ, Bernard S, Schondelmaier J, Weyen J, Quarrie SA (2007) The genetics of nitrogen use in hexaploid wheat: N utilisation, development and yield. Theor Appl Genet 114(3):403-419. doi:10.1007/s00122-006-0429-5

Harper LA, Sharpe RR, Langdale GW, Giddens JE (1987) Nitrogen cycling in a wheat crop-soil, plant and aerial nitrogen transport. Agron J 79(6):965-973

Holland JB (2006) Estimating genotypic correlations and their standard errors using multivariate restricted maximum likelihood estimation with SAS Proc MIXED. Crop Sci 46(2):642-654. doi:10.2135/cropsci2005.0191

Kichey T, Hirel B, Heumez E, Dubois F, Le Gouis J (2007) In winter wheat (Triticum aestivum L.), post-anthesis nitrogen uptake and remobilisation to the grain correlates with agronomic traits and nitrogen physiological markers. Field Crops Res 102(1):22-32

Laperche A, Devienne-Barret F, Maury O, Le Gouis J, Ney B (2006) A simplified conceptual model of carbon/nitrogen functioning for QTL analysis of winter wheat adaptation to nitrogen deficiency. Theor Appl Genet 113(6):1131-1146

Laperche A, Brancourt-Hulmel M, Heumez E, Gardet O, Hanocq E, Devienne-Barret F, Le Gouis J (2007) Using genotype $\mathrm{x}$ nitrogen interaction variables to evaluate the QTL involved in wheat tolerance to nitrogen constraints. Theor Appl Genet 115(3):399-415

Laperche A, Le Gouis J, Hanocq E, Brancourt-Hulmel M (2008) Modelling nitrogen stress with probe genotypes to assess genetic parameters and genetic determinism of winter wheat tolerance to nitrogen constraint. Euphytica 161(1-2):259-271. doi:10.1007/s10681-007-9433-3

Li J, Ji L (2005) Adjusting multiple testing in multilocus analyses using the eigenvalues of a correlation matrix. Heredity 95(3):221-227. doi:10.1038/sj.hdy.6800717
Li XP, Zhao XQ, He X, Zhao GY, Li B, Liu DC, Zhang AM, Zhang XY, Tong YP, Li ZS (2011) Haplotype analysis of the genes encoding glutamine synthetase plastic isoforms and their association with nitrogen-use- and yield-related traits in bread wheat. New Phytol 189(2):449-458. doi:10. 1111/j.1469-8137.2010.03490.x

Lipka AE, Tian F, Wang QS, Peiffer J, Li M, Bradbury PJ, Gore MA, Buckler ES, Zhang ZW (2012) GAPIT: genome association and prediction integrated tool. Bioinformatics 28(18):2397-2399. doi:10.1093/bioinformatics/bts444

Loddo S, Gooding MJ (2012) Semi-dwarfing (Rht-B1b) improves nitrogen-use efficiency in wheat, but not at economically optimal levels of nitrogen availability. Cereal Res Commun 40(1):116-121

Moll RH, Kamprath EJ, Jackson WA (1982) Analysis and interpretation of factors which contribute to efficiency of nitrogen-utilization. Agron J 74(3):562-564

Monaghan JM, Snape JW, Chojecki AJS, Kettlewell PS (2001) The use of grain protein deviation for identifying wheat cultivars with high grain protein concentration and yield. Euphytica 122(2):309-317

Munier-Jolain N, Salon C (2005) Are the carbon costs of seed production related to the quantitative and qualitative performance? An appraisal for legumes and other crops. Plant Cell Environ 28(11):1388-1395

Oury F-X, Godin C (2007) Yield and grain protein concentration in bread wheat: how to use the negative relationship between the two characters to identify favourable genotypes? Euphytica 157(1-2):45-57. doi:10.1007/s10681007-9395-5

Oury FX, Berard P, Brancourt-Hulmel M, Depatureaux C, Doussinault G, Galic N, Giraud A, Heumez E, Lecomte C, Pluchard P, Rolland B, Rousset M, Trottet M (2003) Yield and grain protein concentration in bread wheat: a review and a study of multi-annual data from a French breeding program. J Genet Breed 57(1):59-68

Papakosta DK, Gagianas AA (1991) Nitrogen and dry-matter accumulation, remobilization, and losses for mediterranean wheat during grain filling. Agron J 83(5):864870

Simmonds NW (1995) The relation between yield and protein in cereal grain. J Sci Food Agric 67(3):309-315. doi:10.1002/ jsfa.2740670306

Sun JJ, Guo Y, Zhang GZ, Gao MG, Zhang GH, Kong FM, Zhao Y, Li SS (2013) QTL mapping for seedling traits under different nitrogen forms in wheat. Euphytica 191(3):317-331. doi:10.1007/s10681-012-0834-6

Sylvester-Bradley R, Kindred DR (2009) Analysing nitrogen responses of cereals to prioritize routes to the improvement of nitrogen use efficiency. J Exp Bot 60(7):1939-1951

R Core Team (2016) R: A language and environment for statistical computing., 3.2.3 edn. R Foundation for Statistical Computing, Vienna, Austria

United States Census Bureau, International Programs (2016) International data base: world population. United States Census Bureau. http://www.census.gov/population/ international/data/idb/worldpoptotal.php. Accessed 24 Sept 2016

USDA-ERS (2016) Table 3-World wheat supply and disappearance. United States Department of Agriculture http:// www.ers.usda.gov/datafiles/Wheat_Wheat_Data/Yearbook_ 
Tables/World_Production_Supply_and_Disappearance/ wheatyearbooktable03.xls. Accessed 16 Mar 2013

Waitt DE, Levin DA (1998) Genetic and phenotypic correlations in plants: a botanical test of Cheverud's conjecture. Heredity 80:310-319. doi:10.1046/j.1365-2540.1998. 00298.x

Wang S, Wong D, Forrest K, Allen A, Chao S, Huang BE, Maccaferri M, Salvi S, Milner SG, Cattivelli L, Mastrangelo AM, Whan A, Stephen S, Barker G, Wieseke R, Plieske J, Lillemo M, Mather D, Appels R, Dolferus R, Brown-Guedira G, Korol A, Akhunova AR, Feuillet C, Salse J, Morgante M, Pozniak C, Luo M-C, Dvorak J, Morell M, Dubcovsky J, Ganal M, Tuberosa R, Lawley C, Mikoulitch I, Cavanagh C, Edwards KJ, Hayden M, Akhunov E (2014) Characterization of polyploid wheat genomic diversity using a high-density 90,000 single nucleotide polymorphism array. Plant Biotechnol J 12:787-796

Ward RC (2016) Ward Guide. 154

Warnes G, Gorjanc G, Leisch F, Man M (2013) genetics: Population Genetics. 1.3.8.1 edn.,
Wolfinger RD, Federer WT, Cordero-Brana O (1997) Recovering information in augmented designs, using SAS PROC GLM and PROC MIXED. Agron J 89(6):856-859

Xu YF, Wang RF, Tong YP, Zhao HT, Xie QG, Liu DC, Zhang AM, Li B, Xu HX, An DG (2014) Mapping QTLs for yield and nitrogen-related traits in wheat: influence of nitrogen and phosphorus fertilization on QTL expression. Theor Appl Genet 127(1):59-72. doi:10.1007/s00122-0132201-y

Zhang Z, Ersoz E, Lai C-Q, Todhunter RJ, Tiwari HK, Gore MA, Bradbury PJ, Yu J, Arnett DK, Ordovas JM, Buckler ES (2010) Mixed linear model approach adapted for genome-wide association studies. Nat Genet 42(4):355

Zheng BS, Le Gouis J, Leflon M, Rong WY, Laperche A, Brancourt-Hulmel M (2010) Using probe genotypes to dissect QTL x environment interactions for grain yield components in winter wheat. Theor Appl Genet 121(8):1501-1517 